\title{
1. LEG 146 INTRODUCTION: CASCADIA MARGIN ${ }^{1}$
}

\author{
Shipboard Scientific Party ${ }^{2}$
}

\section{OVERVIEW}

The Cascadia continental margin has evolved in response to subduction of the oceanic Juan de Fuca Plate beneath the North American Plate (Fig. 1). The sedimentary section resting on oceanic lithosphere is a thick accumulation (up to $3.5 \mathrm{~km}$ ) of turbidites and hemipelagic deposits. The lowermost portion of this section is subducted beneath the continental slope as the upper portion is accreted to the margin to form an accretionary wedge. Pore fluids play an important role in determining the mechanical behavior of the deforming sediments, in transferring heat to the seafloor, and in controlling the flux of numerous chemical species within the prism. Ocean Drilling Program (ODP) Leg 146 was directed to the investigation of fluid flow and sediment deformation within the accretionary wedge that forms the Cascadia Margin. The ultimate objective was definition of the budget, sources, and pathways of sediment, water, and dissolved chemicals within the subduction-accretion system.

An important consequence of subduction-induced sediment deformation is that pore fluids are expelled at the seafloor. This discharge may occur as a really dispersed expulsion, or as localized seeps where aquifers intersect the seafloor. Leg 146 set out to evaluate the importance of these flow mechanisms to the fluid budget. Advective flow toward the seafloor brings hydrocarbons, derived from bacterial fermentation and thermal maturation of organic matter, within the gas hydrate stability field at depths of 100-300 m below seafloor (mbsf). Seismic records indicate widespread occurrence on the Cascadia Margin of bottom-simulating reflectors (BSRs) thought to be caused by gas hydrates. Hence, a specific portion of the study of fluid flux was directed to the physical flow and biogeochemical conditions that maintain gas hydrate accumulations.

\section{CASCADIA CONVERGENT MARGIN: REGIONAL GEOLOGY AND TECTONICS}

The Cascadia Margin has been a zone of convergent plate motion since the Eocene, as the Kula/Farallon and, more recently, the Juan de Fuca plates have been subducted obliquely beneath the North American Plate (Riddihough, 1984; Duncan and Kulm, 1989; DeMets et al., 1990). Several terranes have been accreted to the continent, most notably the Crescent and Pacific Rim terranes to the north (Vancouver Island and Olympic Peninsula) and the Klamath Terrane to the south (Snavely, 1987; Hyndman et al., 1990).

\section{Vancouver Island Margin}

The area around southern Vancouver Island includes four tectonic units (Clowes et al., 1987) (Fig. 2A). The island is composed of Paleozoic and Mesozoic rocks (Wrangellia Terrane) that were added to the North American Plate before the Late Cretaceous (Monger et al., 1982; Howell et al., 1985). Just west of the coast lies the Pacific Rim Terrane (Hyndman et al., 1990), which consists of Mesozoic sedimen-

\footnotetext{
${ }^{1}$ Westbrook, G.K., Carson, B., Musgrave, R.J., et al., 1994. Proc. ODP, Init. Repts., 146 (Pt. 1): College Station, TX (Ocean Drilling Program).

${ }^{2}$ Shipboard Scientific Party is as given in the list of participants preceding the contents.
}

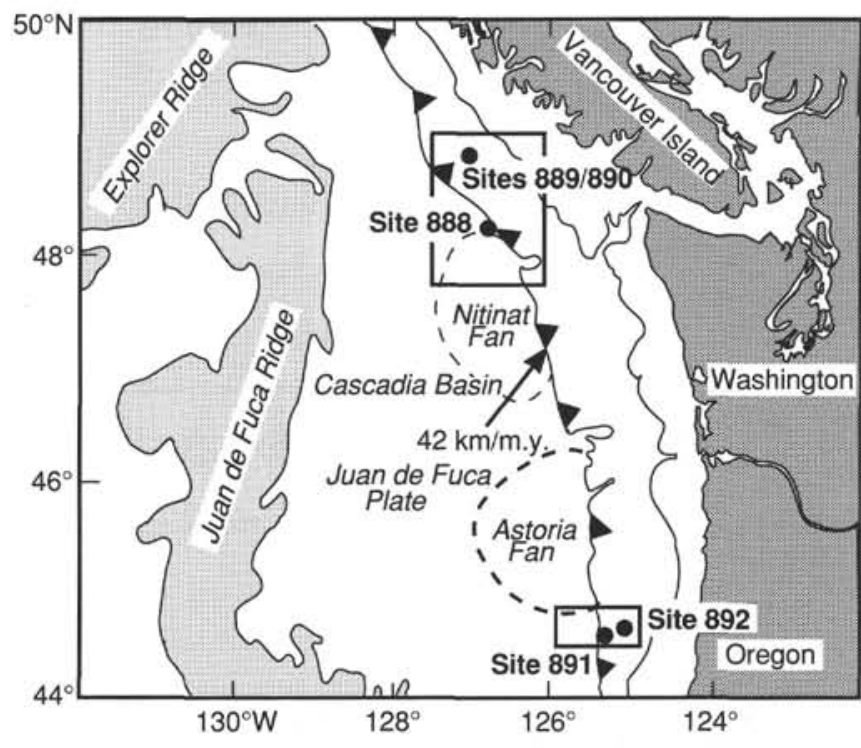

Figure 1. Location map of the Cascadia Margin, showing the convergent plate motion, major physiographic features in the Cascadia Basin (overlying the Juan de Fuca Plate), the position of the continental margin, and the position of drilling sites off Vancouver Island and Oregon.

tary rocks wedged between the older continent and the ophiolites of the Crescent Terrane. The Crescent Formation includes Eocene oceanic crustal rocks, apparently trapped on the margin by a westward jump of the subduction zone (Hyndman et al., 1990). The Pacific Rim and Crescent terranes are assumed to have been emplaced in the same tectonic event. Positioned beneath and west of the Crescent Terrane, the modern accretionary complex has formed by scraping off the incoming sediments from the subducting Juan de Fuca Plate. The evolution of the margin since the Eocene has been relatively simple, and the continuous record of accretion shows no evidence of the arrival of allochthonous terranes (Clowes et al., 1987).

The forearc Tofino Basin, where more than $3000 \mathrm{~m}$ of sediment is deposited, covers most of the continental shelf off Vancouver Island (Yorath, 1987). The basin contains Eocene to Holocene marine clastic sediments that lie over the Pacific Rim and Crescent terranes and the modern sedimentary wedge.

Modern accretion on the northern Cascadia Margin is characterized by thrust faulting that extends nearly to oceanic basement (Hyndman et al., 1990). As a result, in contrast to accretion off Oregon, most of the sedimentary section is transferred to the North American Plate, and little sediment is subducted at present (Davis and Hyndman, 1989; Spence et al., 1991).

\section{Central Oregon Margin}

Off central Oregon, late Tertiary and Quaternary underthrusting of 9-m.y.-old oceanic crust covered by nearly $4 \mathrm{~km}$ of sediment produces a series of well-defined folds and thrust faults in the lower continental slope (MacKay et al., 1992). Deposition is characterized 
A
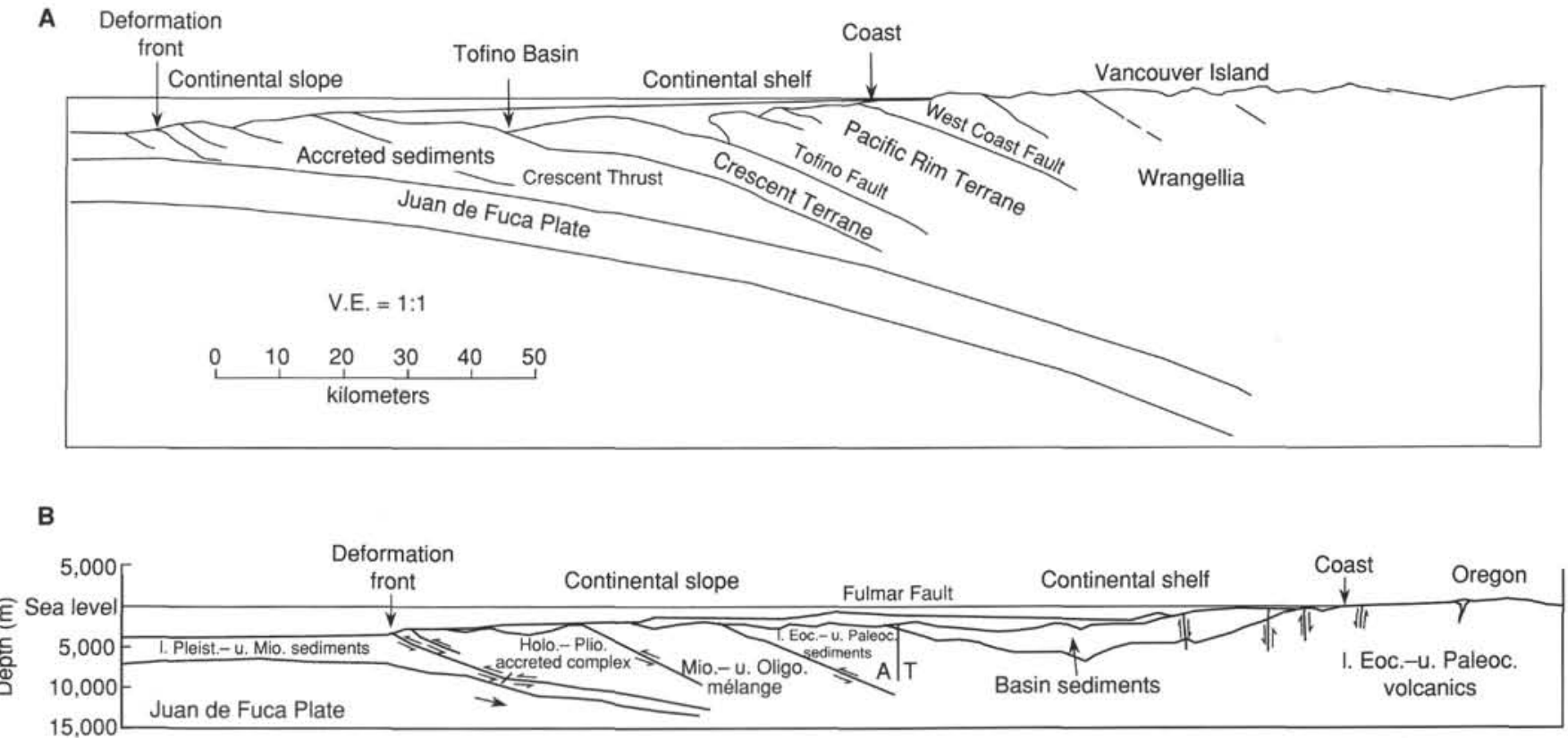

Figure 2. A. Schematic cross section of the Vancouver Island Margin (after Hyndman et al., 1990). B. Schematic cross section of the Oregon Margin at $44^{\circ} 52^{\prime} \mathrm{N}$ (after Snavely et al., 1980). The section is located about $20 \mathrm{~km}$ north of Sites 891-892.

by rapid influx of terrigenous clastics and is manifested by sediment ponds in basins created by folding and faulting on the slope and by large submarine fans in Cascadia Basin. The currently active accretionary wedge is the youngest part of a larger subduction complex that encompasses Paleogene and Neogene portions exposed on land (Snavely et al., 1980) (Fig. 2B).

West of the Coast Range, four distinct geologic provinces are recognizable: (1) a deep forearc basin that lies beneath the inner shelf, (2) a tectonic high that occurs at mid-shelf, (3) an Eocene-Miocene mélange that lies beneath the outer shelf, and (4) folded thrust slices of the Pliocene-Pleistocene accretionary complex that comprise most of the continental slope (Snavely, 1987). Eocene to Miocene sedimentation in the forearc (shelf) basin resulted in the accumulation of more than $7000 \mathrm{~m}$ of sedimentary and volcanic rocks. Convergent episodes in the late Eocene and middle Miocene formed thick, accreted sequences of mélange and broken formations that underlie the present outer shelf and upper continental slope. The modern period of subduction began in the late Miocene, and produced progressive westward migration of the continental slope as abyssal plain/deep-sea fan deposits of the Cascadia Basin were accreted to the margin (Snavely, 1987; Duncan and Kulm, 1989).

\section{Heat Flow and Geothermal Gradient}

Heat flow from the ocean basin is high, about $140 \mathrm{~mW} / \mathrm{m}^{2}$, because of the young age of the oceanic lithosphere ( $8 \mathrm{Ma}$ off Oregon, and 6 Ma off Vancouver). Heat flow decreases landward (Fig. 3A) across the continental margin to about $60 \mathrm{Mw} / \mathrm{m}^{2}$, because the oceanic lithosphere deepens as it is subducted (Langseth and Hobart, 1984; Davis et al., 1990). The initial decrease is accentuated by the tectonic thickening of the accretionary wedge, which stretches the isotherms and reduces the thermal gradient. Local increases and decreases in heat flow over the margin are produced by the effects of thrusting, erosion, localized deposition at high sedimentation rates, and the outflow of warm pore fluids (Wang et al., 1989). For example, a heat-flow high of $182 \mathrm{~mW} / \mathrm{m}^{2}$ measured on the Oregon Margin in a ponded basin between the major thrust sheets is attributed to the advective movement of pore fluids through the accretionary complex (Korgen et al., 1971).
The broad distribution of temperature within the margin off Vancouver Island has been modeled (Ferguson, 1991; R.D. Hyndman, K. Wang, T. Yuan, and G.D. Spence, unpubl. data), taking into account the age of the oceanic lithosphere, the history of sedimentation, and the accretion of sediment at the margin. Beneath the ocean basin floor a temperature of $100^{\circ} \mathrm{C}$ is reached at a depth of $1.3 \mathrm{~km}$, whereas 20 $\mathrm{km}$ landward of the toe of the accretionary wedge, this temperature is reached at a depth of $1.9 \mathrm{~km}$ (Fig. 3B). The pattern of isotherms off Oregon is similar.

\section{BACKGROUND TO SITES 888-890: VANCOUVER ISLAND MARGIN}

\section{Diffuse Pore-fluid Expulsion}

The post-Eocene accretionary wedge off Vancouver Island is scraped off of a 2- to 3-km-thick sediment section on the subducting Juan de Fuca Plate. More than half of this section consists of Pleistocene turbidites, which overlie a thinner sequence of hemipelagites and fine-grained turbidites (von Huene and Kulm, 1973). The first few thrusts of the westwardmost $20 \mathrm{~km}$ or so of the accretionary wedge are rooted in a décollement that lies close to the igneous basement of the subducting oceanic lithosphere. Consequently, virtually all of the sedimentary section has been accreted to the wedge in this interval. However, comparison of the cross-sectional area of the accretionary wedge with that of the Cascadia Basin sedimentary section shows that a substantial portion of the section has been subducted over the 42 m.y. history of continuous accretion, unless the thickness of the sedimentary section was much less in the past.

Two types of data provide information on fluid expulsion and porosity reduction across the active deformation zone on the Vancouver Island Margin: porosity distribution derived from multichannel seismic velocity data (Davis and Hyndman, 1989; T. Yuan, G.D. Spence, and R.D. Hyndman, unpubl. data); and inferred vertical fluid flow from analysis of the thermal regime (Hyndman and Davis, 1992; Wang et al., 1993; R.D. Hyndman, K. Wang, T. Yuan, and G.D. Spence, unpubl. data). Neither of these techniques defines localized (focused) fluid discharge, but reflect regional fluid loss. One of the primary drilling objectives of Leg 146 was to investigate how compaction affects dispersed fluid expulsion. 

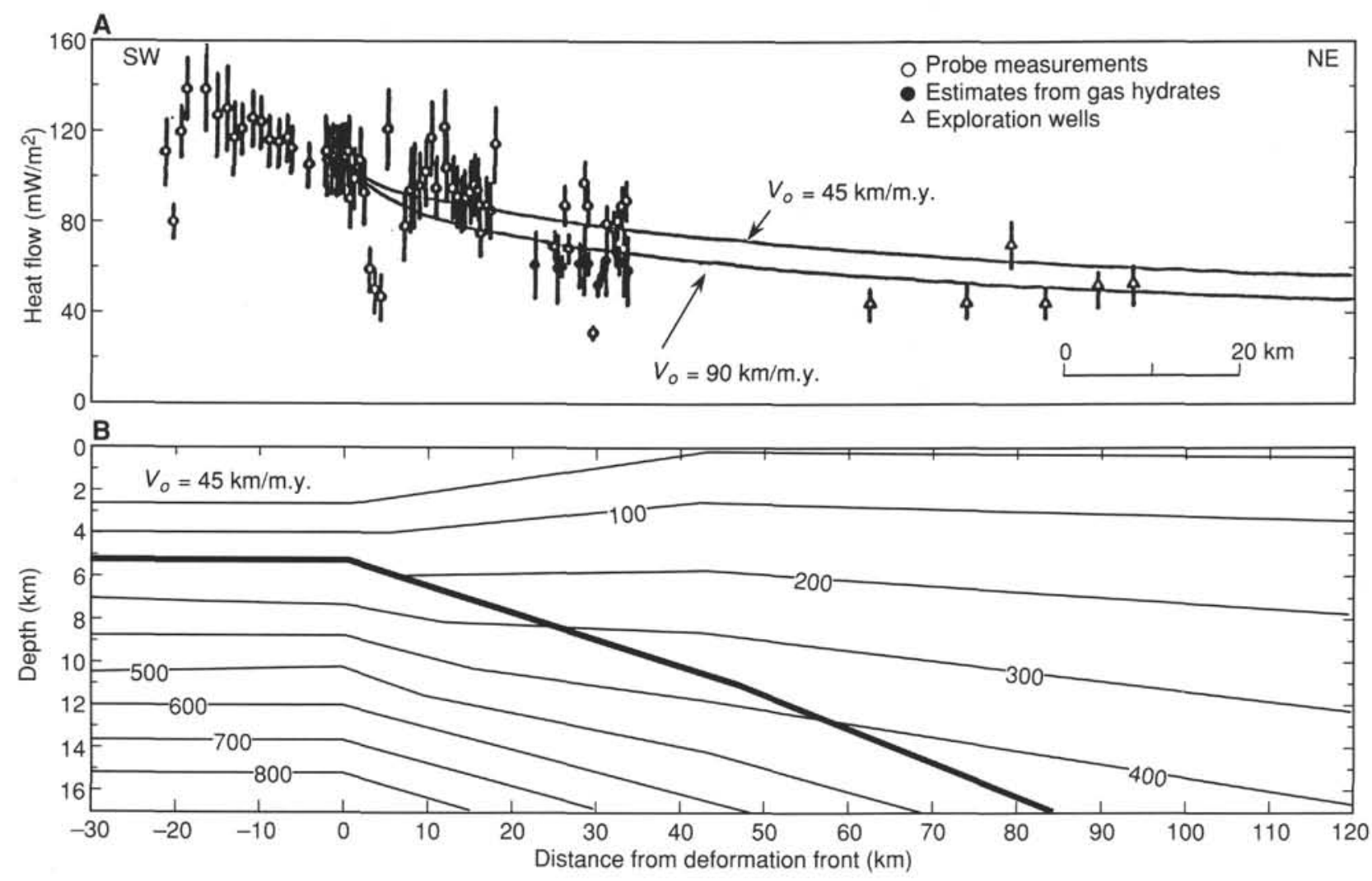

Figure 3. A. Heat-flow data and predicted heat-flow distribution for the Vancouver Island continental margin (after Ferguson, 1991). B. Predicted temperature distribution for constant subduction rate of $45 \mathrm{~km} / \mathrm{m}$.y. The heavy line is the top of the oceanic crust (after Ferguson, 1991). Isotherms are shown in ${ }^{\circ} \mathrm{C}$.

Porosity-depth profiles derived from multichannel seismic velocities for three regions on the Vancouver Island Margin (seaward of the deformation front, just behind the front, and the area about $10 \mathrm{~km}$ farther landward of the front) show a general porosity decrease of about $10 \%$ in the upper 1 to $2 \mathrm{~km}$ of sediment over a distance of $20 \mathrm{~km}$ (Davis and Hyndman, 1989). As calculated using the convergence and sediment-accretion rates, the estimated diffuse fluid expulsion rate required to give this rate of porosity change is approximately $1 \times 10^{-10} \mathrm{~m} / \mathrm{s}(3$ $\mathrm{cm} / \mathrm{yr}$ ). Within this regional pattern, however, variations in compaction occur across the lowermost elements of the wedge, which are related to faulting and deformation (T. Yuan, G.D. Spence, and R.D. Hyndman, unpubl. data). In the seaward-verging thrust sheets of the lower slope (Fig. 4), porosity is low (velocity high) seaward of the fault traces, apparently as a result of tectonic consolidation associated with thrusting. Fluids squeezed from these sediments may be channeled along the fault zones. Landward of each thrust fault the porosity is significantly higher (velocity lower), with values close to those in the undeformed sequence in Cascadia Basin. These data suggest that fluid expulsion may be laterally heterogeneous, at least on the youngest portions of the wedge. Similar patterns have been observed off Oregon (Lewis, 1992) and Barbados (Bangs et al., 1990).

A complementary estimate of dispersed fluid flow is obtained from thermal data (Davis et al., 1990). Heat flow was measured at the seabed by 110 probe measurements and was estimated from the depth of the BSR (Fig. 3A) on the assumption that the BSR represents the base of the stability field for methane hydrate. The heat-flow values derived from the BSR analysis were systematically lower than for the nearly coincident probe measurements, with some tendency for the difference to decrease landward. It was postulated (Davis et al., 1990) that vertical advective fluid flow is responsible for the difference. The effect is illustrated in Figure 5 for a point about $10 \mathrm{~km}$ inland of the deformation front. The temperature at the depth of the BSR obtained by extrapolating the surface temperature gradient downward using estimated values of thermal conductivity is substantially higher than the temperature derived from the hydrate stability field. A simple, vertically advective fluid-flow model could resolve the disparity if the near-surface flow rate were about $1 \times 10^{-9} \mathrm{~m} / \mathrm{s}(30 \mathrm{~cm} / \mathrm{yr})$. Because this flow rate is an order of magnitude greater than that estimated from porosity loss, it is crucial to calibrate the temperature and pressure at which the BSR forms. It is equally important to make formation pressure and permeability measurements at the same location so that the thermally derived estimate of flow can be compared with flow calculated by standard hydrogeological techniques.

\section{BSR Hydrate Formation}

The BSRs commonly occur several hundred meters beneath the seafloor in continental slope sediments, particularly in accretionary wedges at subduction zones (Shipley et al., 1979; Kvenvolden and Barnard, 1983). That these reflectors mark the base of the region of hydrate stability is inferred from a number of observations, notably that the pressure and temperature conditions estimated for the BSRs agree with the maximum temperature and pressure at which hydrate is stable from laboratory data and that interstitial and massive hydrates have been recovered in Deep Sea Drilling Project (DSDP) cores from sections above BSRs (Kvenvolden and Barnard, 1983; Suess et al., 1988).

Several studies (Hand et al., 1984; Miller, 1984; Hyndman and Davis, 1992; Miller et al., 1991; Hyndman and Spence, 1992) have focused on the problem of the vertical distribution of hydrate and possible free gas required to generate BSRs. The main results are (1) the reversal of the polarity of the reflection indicates that, for a simple interface, acoustic impedance (velocity $\times$ density) is lower below the boundary; (2) the BSR reflection coefficients are large, commonly $50 \%$ of those of the seafloor reflection; (3) multichannel and other 


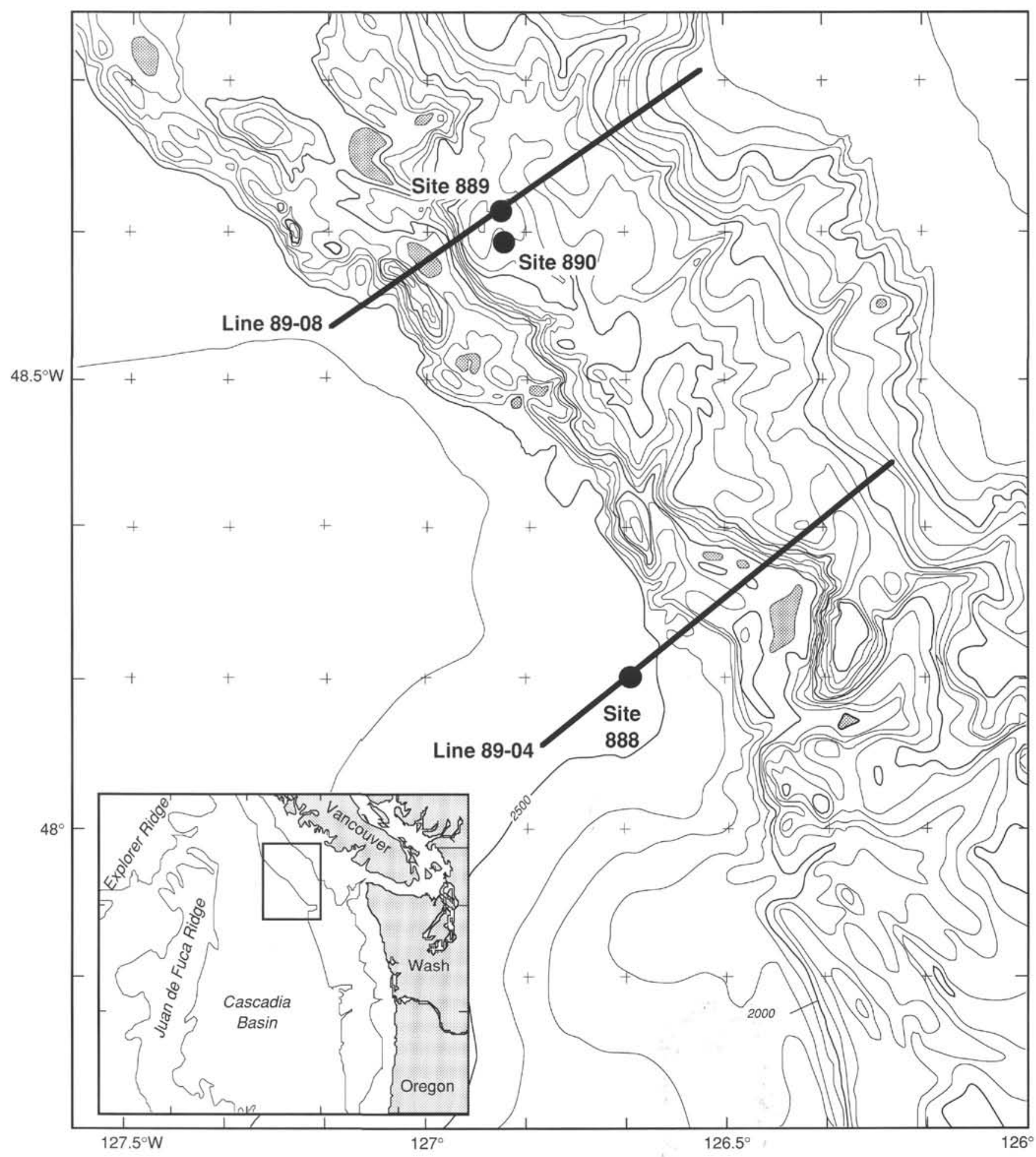

Figure 4. Position of drill Sites 888-890 and seismic lines 89-08 and 89-04, off Vancouver Island.

seismic velocity data indicate that there is generally little increase in average velocity in the sediment section from the seafloor to the BSR, which indicates that the hydrate is concentrated at the base of the stability field (i.e., no more than several tens of meters thick); and (4) the BSR must be at least one-quarter wavelength thick $(5-10 \mathrm{~m}$ minimum) and there must be an abrupt contrast at the base of the layer. The lack of a reflection from the upper boundary of the hydrate layer indicates that the upper boundary is a gradual transition.
Drilling at Site 889 tested a number of conflicting hypotheses about the geochemical conditions under which gas hydrates form, their distribution and concentration within the sediment column, and the movement of pore fluids associated with them. Fundamental questions to be answered included the following:

1. Is methane the only gas involved or are other gases also hydrated? 
2. Is the methane derived locally or is it advected to the hydrated zone (clathrate stability field) by pore fluids from greater depths?

3 . Is the gas exclusively biogenic or is it mixed with thermogenic gas?

4. Is advection necessary to account for the volume of hydrated gas present?

5. Is the base of the hydrate layer (which defines the BSR) underlain by gas-saturated pore waters with free gas present or can the fluids be undersaturated?

6. How is the concentration of hydrated gas distributed across the stability field, and how does the gas alter the free porosity distribution?

7. Is the hydrated zone permeable to fluid flow or does it provide a seal to upward fluid advection?

\section{BACKGROUND TO SITES 891-892: CENTRAL OREGON MARGIN}

\section{Focused Pore-fluid Expulsion}

Subduction-related deformation off Oregon begins on the abyssal plain about 3-6 km seaward of the toe of the accretionary wedge (Fig. 6), with the development of incipient thrust faults (MacKay et al., 1992). A small landward increase in seismic velocities in the upper part of the sedimentary section (Lewis, 1992; G.R. Cochrane, J.C. Moore, M.E. MacKay, and G.F. Moore, unpubl. data) probably reflects a progressive porosity reduction approaching the wedge through this proto-deformation zone. Analysis of images from GLORIA longrange sidescan sonar (Carson et al., 1991) indicate that cementation of near-surface sediments occurs in the same region, presumably owing to methane oxidation (Ritger et al., 1987) in pore fluids expelled by the compaction process.

Anticlinal ridges that parallel the base of the continental slope are caused by movement along thrust faults and by folding. Between $44^{\circ} 32^{\prime} \mathrm{N}$ and $44^{\circ} 42^{\prime} \mathrm{N}$ (Figs. 6-7), landward-dipping thrusts sole in a décollement interval at about $2 \mathrm{~km}$, a position equivalent to the middle of the incoming sedimentary section. Thrusting creates a prominent ramp anticline that underlies the marginal ridge (MacKay et al., 1992), and is cut by a backthrust that emerges just landward of the fold axis (Moore et al., 1990). Landward-dipping thrusts occur upslope on the second ridge, although their subsurface position is apparent only near the surface, as individual reflectors are laterally incoherent. Direct submersible observations and definition by sidescan imagery of extensive carbonate deposition along the fault traces demonstrate that many of these fractures are or have been active fluid conduits (Kulm et al., 1986; Lewis and Cochrane, 1990; Moore et al., 1990; Carson et al., 1991). A thrust fault just west of the crest of the second ridge appears to be a particularly active aquifer because it is surrounded by large volumes of diagenetic carbonates (Carson et al., 1991) and exhibits upward displacement of the BSR, probably in response to the advection of warm fluid (J.C. Moore, unpubl. data). The BSR is resolved generally about $10 \mathrm{~km}$ landward of the frontal thrust (Fig. 6). As off much of the Vancouver Island Margin, the BSR is not prominently developed close to the base of the continental slope.

North of the section described in the preceding, between $44^{\circ} 50^{\prime} \mathrm{N}$ and $45^{\circ} 06^{\prime} \mathrm{N}$, seaward-dipping thrusts (or landward-vergent thrustpropagation folds) predominate at the toe of the wedge. These faults are rooted near the base of the sedimentary section, about $4 \mathrm{~km}$ sub-bottom (MacKay et al., 1992). If the frontal thrusts are important aquifers, then fluids from deep below Cascadia Basin may have their source near basement in this region. In contrast, in the seaward-vergent area farther south, the position of the décollement, at a depth of about $2 \mathrm{~km}$, suggests a fluid source beneath the accretionary wedge wholly within the sediment column.

More than 10 sites of fluid venting have been discovered along the foot of the wedge (i.e., along the first ridge in the southern area (Fig. 6) and on the incipient fold on the abyssal plain in the northern area) during $A L V I N$ dive programs on the lower Oregon slope (Moore et al., 1990). Many of the vent sites are characterized by chemosynthetic animal communities, by the expulsion of methane or methane and hydrogen sulfide, and by authigenic carbonate deposits (Suess et al., 1985; Kulm et al., 1986). The methane in the fluids is highly depleted in carbon- 13 ( -66 to $-73 \delta^{13} \mathrm{C}$ relative to the PeeDee belemnite standard), which indicates a microbial origin and probable derivation from shallow levels ( $<1 \mathrm{~km}$ sub-bottom) of the accretionary complex (Suess and Whiticar, 1989). The presence of both hydrogen sulfide and methane in fluids venting from one location on the marginal ridge but methane only in fluids at another site may reflect either variable fluid sources or reaction and differentiation during subsurface advection. Helium concentrations and isotopes from waters collected in situ from the vents show that fluids from the southern area have a strong radiogenic component, which implies that they were generated entirely within the accretionary sediment pile. Conversely, preliminary evidence indicates that the fluids venting from a deeply rooted fault-fold intersection in the northern area have some primordial component, suggesting contact with oceanic basement (E. Suess, pers. comm., 1992).

Rates of fluid flow from local vent sites on the marginal ridge in the southern area have been estimated from dissolved methane transfer and directly measured by flow meters (Carson et al., 1990). The results imply a subsurface advective flow rate of about $100 \mathrm{~m} / \mathrm{yr}$. These discharge rates are several orders of magnitude higher than rates calculated for steady-state expulsion as a result of accretionrelated consolidation, indicating that the flow through vents is spatially focused and probably episodic. Methane concentrations measured at vents in the northern and southern areas off Oregon vary by a factor of at least 300 and demonstrate a heterogeneous distribution of flow paths and fluid discharge.

Flow is almost certainly focused by inhomogeneities in permeability. Measurement of samples collected from the walls of the submarine canyon just north of Site 891 show a permeability ranging from approximately $10^{-4}$ to $10^{2} \mathrm{mD}\left(\right.$ mean $\left.=10^{-1} \mathrm{mD}\right)$ with no obvious control by grain size (Fig. 8). Despite the generally low permeability, however, no doubt exists that large volumes of fluid have been expelled in the accretion process. The porosity of the accreted slope sediments is low, averaging $46 \%$ for surface samples (Carson, 1977) and has been estimated from seismic velocity to decline to about $12 \%$ at $2.2 \mathrm{~km}$, the depth of the décollement (Fig. 9). The apparent contradiction of high-volume discharge and low permeability has been observationally (qualitatively) resolved: flow is concentrated along stratigraphic aquifers or high-permeability fault zones (Lewis and Cochrane, 1990; Moore et al., 1990). What remains to be ascertained are the hydrogeologic conditions under which this flow occurs, the subsurface composition of the fluids and geochemical signatures left by them, and the distribution of the physical properties that control flow.

\section{DRILLING OBJECTIVES AND APPROACHES}

The overall objective of Leg 146 was to evaluate the role of fluid flow in the structural development of the Cascadia accretionary wedge and to determine how that flow controls the composition, distribution, concentration, and flux of biogeochemical species. Within this broad context, the drilling program had the following specific objectives:

1. To determine the distribution of (and by implication, the temporal changes in) porosity from undeformed Cascadia Basin sediments across the lower, active portions of the accretionary wedge by calibrating the porosity estimated from seismic velocity. These data are fundamental for assessing the water budget for the accretionary prism.

2. To measure the physical properties of the sediments, identify their diagenetic alteration products, and relate the compaction dynamics and rates of alteration to stages of macroscopic to microscopic structural evolution and fluid loss.

3. To delineate the major fluid migration pathways (permeable stratigraphic layers, faults, diffuse flow) and to discover whether flow is active presently or has been active in the past. These pathways may 


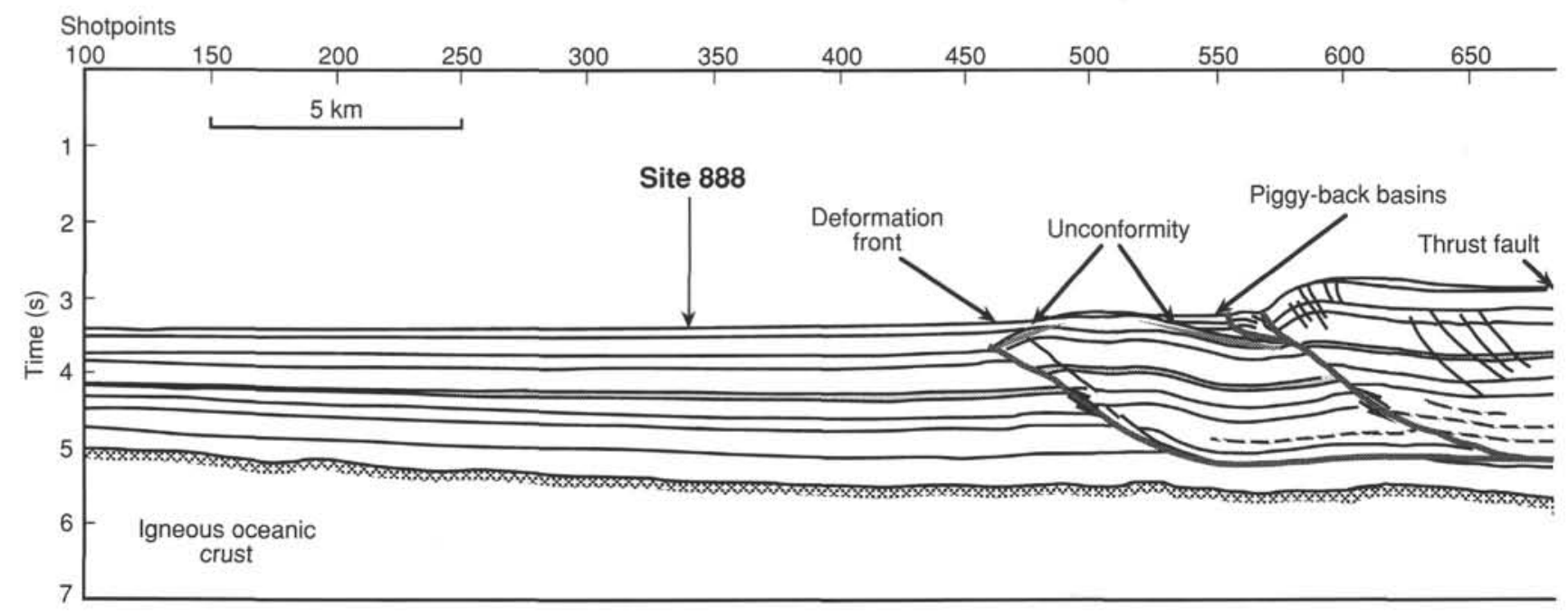

Figure 5. Migrated seismic-reflection section 89-04, showing flat-lying Cascadia Basin deposits (Shotpoints 200-460), coherent deformation zone cut by deeply seated, seaward-verging thrust faults (Shotpoints 460-760), and the incoherent deformation zone (landward of Shotpoint 760). Also plotted is the position of Site 888, and the relative position (migrated $56 \mathrm{~km}$ southeast) of Sites 889 and 890 .

not vary only with the structural style of accretion, but may also change progressively as the physical properties and structural fabrics of the sediments change.

4. To define the hydrogeologic properties (permeabilities, pressure gradients) of fluid expulsion pathways so that we may put realistic constraints on models of fluid flow.

5. To determine the composition and sources of pore fluids and evaluate the flux of geochemical species and the nature of fluid-rock interaction.

6. To determine the nature of gas hydrates and to define the hydrogeologic, microbial, geochemical, and thermal conditions under which they form and are maintained.

These objectives were addressed by an integrated science program that emphasized downhole measurements as strongly as the data obtained from examination of the recovered samples. The borehole seals installed on Leg 146 presage long-term investigations, which we expect to be continued in future ODP studies of accretionary wedges, of the pore fluids and hydrologic characteristics of the sediments after the dissipation of drilling-induced disturbances. The investigations reported in this volume and its companion (Leg 146 Scientific Results) demonstrate the unusual variety and integration of measurement and sampling programs used to accomplish these objectives. The strategies employed to address the specific objectives are summarized as follows:

1. The porosity distribution was defined by shipboard determinations on returned cores (gamma-ray attenuation porosity evaluator, resistivity, and volume/gravimetric determinations) and downhole logs (resistivity, neutron, and formation density), and related to regional seismic reflection data through vertical seismic profiles and sonic logs.

2. Measurements of physical properties, the geochemistry of pore water and solids, and structural studies on core samples were used to define the synergism between consolidation, fluid composition, diagenetic reactions, and development of structural features. Carbonate cementation is a common, microbially mediated, diagenetic reaction in near-surface sediments. Drilling was aimed to determine if comparable reactions occur at depth, how such reactions affect the strength and porosity of the sediment, what effect they have on pore-water composition and isotopic distribution, and if they are associated with the development of particular deformation-induced structures or fab- rics. Downhole logging and borehole imaging with the Formation MicroScanner provided in-situ determinations of the occurrence and distribution of physical properties and structural features to augment the core studies.

3. The drilling sites on the Cascadia Margin were positioned to evaluate a variety of inferred flow paths. Off Vancouver Island, Site 889 is located over a strong, nearly horizontal gas hydrate reflector, which is thought to be sustained by diffuse, upward-advecting fluid flow in a section unaffected by major faults (Hyndman and Davis, 1992). Off Oregon, the drilling sites intersect both fault zones and strongly reflective stratigraphic horizons (inferred to be thick turbidite sands) that may support flow. Active flow should be apparent in both temperature and geochemical anomalies; strong fluid expulsion into a hole ought to be shown by the temperature log. Evidence for past flow may vary depending upon the time elapsed since advection ceased. Geochemical anomalies in pore-water composition in the absence of temperature anomalies indicate relatively recent cessation of flow. With time, the geochemical anomalies become increasingly diffuse along the concentration gradient. Past flow is also evidenced by the precipitation of veins and cements that require many pore volumes of flow and should be apparent in the density, natural gamma, or velocity logs.

4. Having identified those pathways that support flow, packer tests and the Lateral Stress Tool (LAST-II) were deployed in boreholes on both the Vancouver and Oregon margins to measure formation pressure. In-situ permeability values were derived from slug tests that are integrated over the open portions of the holes (ODP packer). Longer term determinations of pressure and permeability are planned in Holes $889 \mathrm{~B}$ and $892 \mathrm{~B}$, which are hydraulically isolated by the CORK borehole seals. At each of these sites, post-drilling pressure (and temperature; see Strategy 3 above) recovery will be recorded for a two-year period, and drawdown tests (venting of the boreholes while monitoring discharge and pressure response) will be conducted by using a submersible within the first year after drilling. These pressure and permeability determinations will provide the first field measurements in an accretionary wedge of these parameters, which are critical to hydrogeologic modeling.

5. Evidence for the sources of pore waters comes primarily from the geochemical composition of the fluids. Chloride anomalies point to flow conduits and potential fluid sources. The isotopic composition of methane and the absence or occurrence of higher order homologues indicates whether the gas has a biogenic, thermogenic, or mixed origin and, concomitantly, whether the source was shallow or deep. The gas 


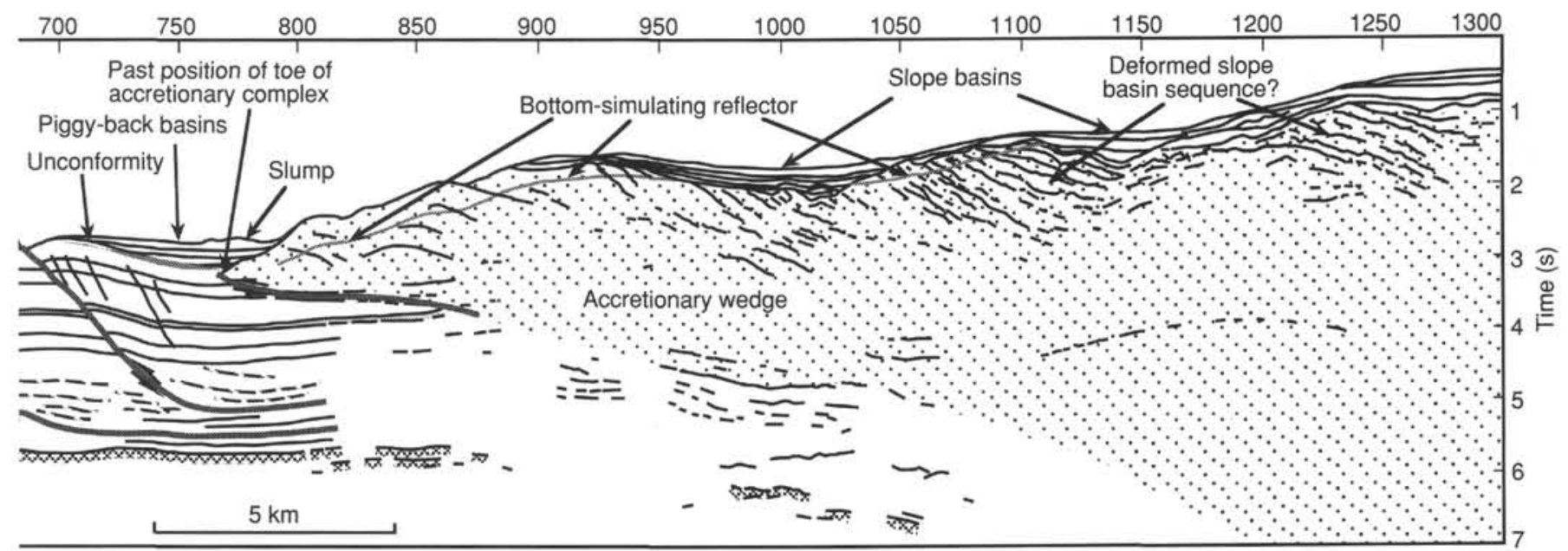

Figure 5 (continued).

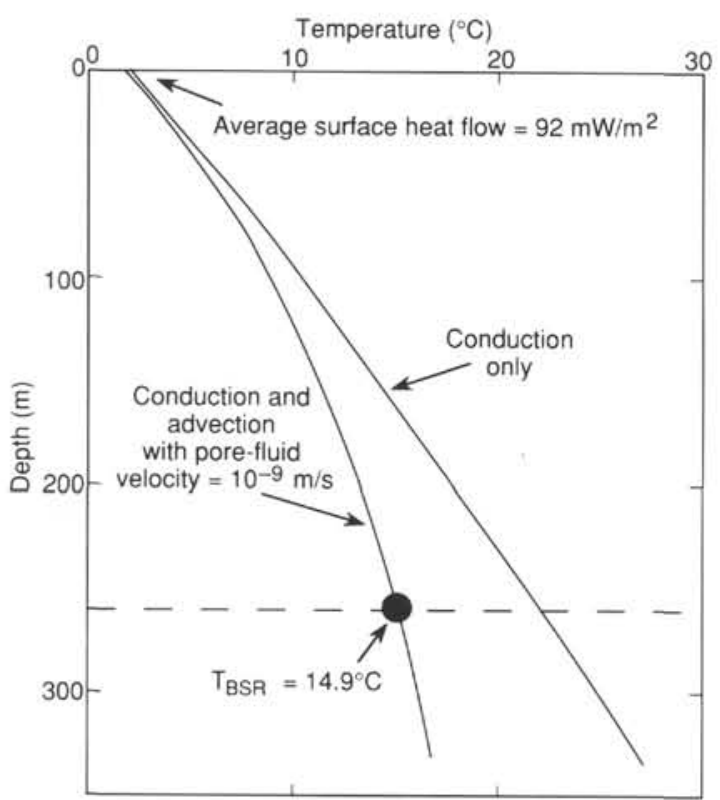

Figure 6. Position of Sites 891 and 892 and seismic Line OR-9 off Oregon. The positions of thrust fault traces are indicated by heavy toothed lines. The seaward limits of the proto-deformation zone and of the BSR are shown by heavy gray lines. After MacKay et al. (1992).

composition also has implications for the extent of migration, although the evidence is seldom definitive. In contrast, $\mathrm{He}$ isotopes are sensitive indicators of fluid contributions from the sedimentary (radiogenic) section vs. an oceanic crustal (primordial) source. In a similar fashion, isotopes of strontium, because they do not fractionate upon reaction, indicate seawater, oceanic crust, and/or continental contributions. Other species, notably oxygen and hydrogen, readily fractionate isotopically and their distribution in interstitial waters reflects the effects of continent-derived groundwater, gas-hydrate dissociation, mineral dehydration, or clay membrane ultrafiltration. The comprehensive pore-water geochemistry program constrains the potential sources of fluids in the Cascadia Margin, and the complementary cements derived from advecting fluids indicate the biogeochemical sinks that affect the mass flux in this accretionary system.

6. High-amplitude BSRs occur at Sites 889 and 892 in different structural and hydrologic regimes. At Site 889 , the BSR, which is horizontal within an incoherent seismic zone, may be maintained by diffuse, upward-advecting, hydrocarbon-bearing pore fluids. At Site 892, the BSR crosses an actively venting, out-of-sequence thrust fault. The BSR at this location is displaced toward the surface, probably by the increased temperature produced by the flow of warm fluids along the fault. An extensive program of sampling (including geochemical analyses of material collected with the pressure core sampler, the bacteriological study of sections cut from cores recovered with the standard advanced piston corer and extended core barrel, downhole logging, packer tests, post-cruise CORK experiments at Sites 889 and892, and thermal conductivity/temperature determinations) provide the most complete investigation of active hydrate layers undertaken by the Ocean Drilling Program.

\section{REFERENCES *}

Bangs, N.L.B., Westbrook, G.K., Ladd, J.W., and Buhl, P., 1990. Seismic velocities from the Barbados Ridge complex: indicators of high pore fluid pressures in an accretionary complex. J. Geophys, Res., 95:8767-8782.

Carson, B., 1977. Tectonically induced deformation of deep-sea sediments off Washington and northern Oregon: mechanical consolidation. Mar. Geol., 24:289-307.

Carson, B., Holmes, M.L., Umstattd, K., Strasser, J.C., and Johnson, H.P., 1991. Fluid expulsion from the Cascadia accretionary prism: evidence from porosity distribution, direct measurements, and GLORIA imagery. Trans. R. Soc. London A, 335:331-340.

Carson, B., Suess, E., and Strasser, J.C., 1990. Fluid flow and mass flux determinations at vent sites on the Cascadia Margin accretionary prism. J. Geophys. Res., 95:8891-8898.

Clowes, R.M., Brandon, M.T., Green, A.G., Yorath, C.J., Brown, A.S., Kanasewich, E.R., and Spencer, C., 1987. LITHOPROBE-southern Vancouver Island: Cenozoic subduction complex imaged by deep seismic reflections. Can. J. Earth Sci., 24:31-51.

Davis, E.E., and Hyndman, R.D., 1989. Accretion and recent deformation of sediments along the northern Cascadia subduction zone. Geol. Soc. Am. Bull., 101:1465-1480.

Davis, E.E., Hyndman, R.D., and Villinger, H., 1990. Rates of fluid expulsion across the northern Cascadia accretionary prism: constraints from new heat flow and multichannel seismic data. J. Geophys. Res., 95:8869-8890.

\footnotetext{
*Abbreviations for names of organizations and publication titles in ODP reference lists follow the style given in Chemical Abstracts Service Source Index (published by American Chemical Society).
} 
DeMets, C., Gordon, R.G., Argus, D.F., and Stein, S., 1990. Current plate motions. Geophys. J. Int., 101:425-478.

Duncan, R.A., and Kulm, L.D., 1989. Plate tectonic evolution of the Cascades arc-subduction complex. In Winterer, E.L., Hussong, D.M., and Decker, R.W. (Eds.), The Eastern Pacific Ocean and Hawaii. Geol. Soc. Am., 413-438.

Ferguson, I.J., 1991. Numerical modelling of heat flow and fluid flow in subduction-accretion complexes [Ph.D. thesis]. Univ, of Birmingham.

Hand, J.H., Katz, D.L., and Verma, V.K., 1984. Review of gas hydrates with implications for ocean sediments. In Kaplan, I.R. (Ed.), Natural Gases in Marine Sediments: New York (Plenum), 179-194.

Howell, D.G., Jones, D.L., and Schermer, E.R., 1985. Tectonostratigraphic terranes of the circum-Pacific region. In Preliminary Tectonostratigraphic Terrane Map of the Circum-Pacific Region. AAPG.

Hyndman, R.D., and Davis, E.E., 1992. A mechanism for the formation of methane hydrate and seafloor bottom simulating reflectors by vertical fluid expulsion. J. Geophys. Res., 97:7025-7041.

Hyndman, R.D., and Spence, G.D., 1992. A seismic study of methane hydrate marine bottom simulating reflectors. J. Geophys. Res., 97:6683-6698.

Hyndman, R.D., Yorath, C.J., Clowes, R.M., and Davis, E.E., 1990. The northern Cascadia subduction at Vancouver Island: seismic structure and tectonic history. Can. J. Earth Sci., 27:313-319.

Korgen, B.J., Bodvarsson, G., and Mesecar, R.S., 1971. Heat flow through the floor of the Cascadia Basin. J. Geophys. Res., 76:4758-4774.

Kulm, L.D., Suess, E., Moore, J.C., Carson, B., Lewis, B.T., Ritger, S.D., Kadko, D.C., Thornburg, T.M., Embley, R.W., Rugh, W.D., Massoth, G.J., Langseth, M.G., Cochrane, G.R., and Scamman, R.L., 1986. Oregon subduction zone: venting, fauna, and carbonates. Science, 231:561-566.

Kvenvolden, K.A., and Barnard, L.A., 1983. Hydrates of natural gas in continental margins. In Watkins, J.S., and Drake, C.L. (Eds.), Studies in Continental Margin Geology. AAPG, 631-640.

Langseth, M.G., and Hobart, M.A., 1984. A marine geothermal study over deformed sediments of the subduction complex off Oregon and Washington. Eos, 65:1089.

Lewis, B.T.R., 1992. Changes in P and S velocities caused by subduction related sediment accretion off Washington/Oregon. In Koven, J., and Stoll, R. (Eds.), Shear Wave in Marine Sediments: Boston (Kluwer Academic), 379-386.

Lewis, B.T.R., and Cochrane, G.R., 1990. Relationship between the location of chemosynthetic benthic communities and geologic structure on the Cascadia subduction zone. J. Geophys. Res., 95:8783-8793.

MacKay, M.E., Moore, G.F., Cochrane, G.R., Moore, J.C., and Kulm, L.D., 1992. Landward vergence and oblique structural trends in the Oregon Margin accretionary prism: implications and effect on fluid flow. Earth Planet. Sci. Lett., 109:477-491.

Miller, J.J., Lee, M.W., and von Huene, R., 1991. An analysis of a seismic reflection from the base of a gas hydrate zone, offshore Peru. AAPG Bull., 75:910-924.

Miller, S.L., 1984. The nature and occurrence of clathrate hydrates. In Kaplan, I.R. (Ed.), Natural Gases in Marine Sediments: New York (Plenum), $151-177$.

Monger, J.W.H., Price, R.A., and Tempelman-Kluit, D.J., 1982. Tectonic accretion and the origin of the two major metamorphic and plutonic welts in the Canadian Cordillera. Geology, 10:7075.
Moore, J.C., Orange, D., and Kulm, L.D., 1990. Interrelationship of fluid venting and structural evolution: Alvin observations from the frontal accretionary prism. J. Geophys. Res., 95:8795-8808.

Riddihough, R.P., 1984. Recent movements of the Juan de Fuca Plate system. J. Geophys. Res., 89:6980-6994.

Ritger, S., Carson, B., and Suess, E., 1987. Methane-derived authigenic carbonates formed by subduction-induced pore-water expulsion along the Oregon/Washington Margin. Geol. Soc. Am. Bull., 98:147-156.

Shipley, T.H., Houston, R.T., Buffler, R.T., Shaub, F.J., McMillen, K.J., Ladd, J.W., and Worzel, J.L., 1979. Seismic evidence for widespread possible gas hydrate horizons on continental slopes and rises. AAPG Bull., 63:2204 2213.

Snavely, P.D., Jr., 1987. Tertiary geologic framework, neotectonics, and petroleum potential of the Oregon-Washington continental margin. In Scholl, D.W., Grantz, A., and Vedder, J.G. (Eds.), Geology and Resource Potential of the Continental Margin of Western North America and Adjacent Ocean Basins-Beaufort Sea to Baja California. Circum-Pac. Counc. Energy Miner. Resourc., 305-336.

Snavely, P.D., Jr., Wagner, H.C., and Lander, D.L., 1980. Geologic cross section of the central Oregon continental margin. Geol. Soc. Am., Map and Chart Ser., MC-28J.

Spence, G.D., Hyndman, R.D., et al., 1991. Seismic structure of the northern Cascadia accretionary prism: evidence from new multichannel seismic reflection data. In Meissner, R., Brown, L., Birbaiet, W., Franke, K., Fuchs, K., and Seifert, F. (Eds.), Continental Lithosphere, Deep Seismic Reflection. Am. Geophys. Union, Geodyn. Ser., 22:257-263.

Suess, E., Carson, B., Ritger, S., Moore, J.C., Jones, M., Kulm, L.D., and Cochrane, G., 1985. Biological communities at vent sites along the subduction zones off Oregon. In Jones, M.L. (Ed.), The Hydrothermal Vents of the Eastern Pacific: An Overview. Bull. Biol. Soc. Wash., 475-484.

Suess, E., von Huene, R., and the Leg 112 Shipboard Scientists, 1988. Ocean Drilling Program Leg 112, Peru continental margin: Part 2, Sedimentary history and diagenesis in a coastal upwelling environment. Geology, 16:939-943.

Suess, E., and Whiticar, M.J., 1989. Methane-derived $\mathrm{CO}_{2}$ in pore fluids expelled from the Oregon subduction zone. Palaeogeogr., Palaeoclimatol. Palaeoecol., 71:119-136.

von Huene, R., and Kulm, L.D., 1973. Tectonic summary of Leg 18. In Kulm, L.D., von Huene, R., et al., Init. Repts. DSDP: Washington (U.S. Govt. Printing Office), 961-976.

Wang, C.-Y., Shi, Y., Kulm, L.D., and Langseth, M.B., 1989. Thermal constraints on fluid expulsion rate in accretionary prism-a study of the Oregon-Washington Margin. Eos, 70:1333.

Wang, K., Hyndman, R.D., and Davis, E.E., 1993. Thermal effects of sediment thickening and fluid expulsion in accretionary prisms: model and parameter analysis. J. Geophys. Res., 98:9975-9984.

Yorath, C.J., 1987. Petroleum geology of the Canadian Pacific continental margin. In Scholl, D.W., Grantz, A., and Vedder, J.G. (Eds.), Geology and Resource Potential of the Continental Margin of Western North America and Adjacent Ocean Basins-Beaufort Sea to Baja California. CircumPac. Counc. Energy Miner. Resourc., 283-304.

\section{Ms 146IR-001}




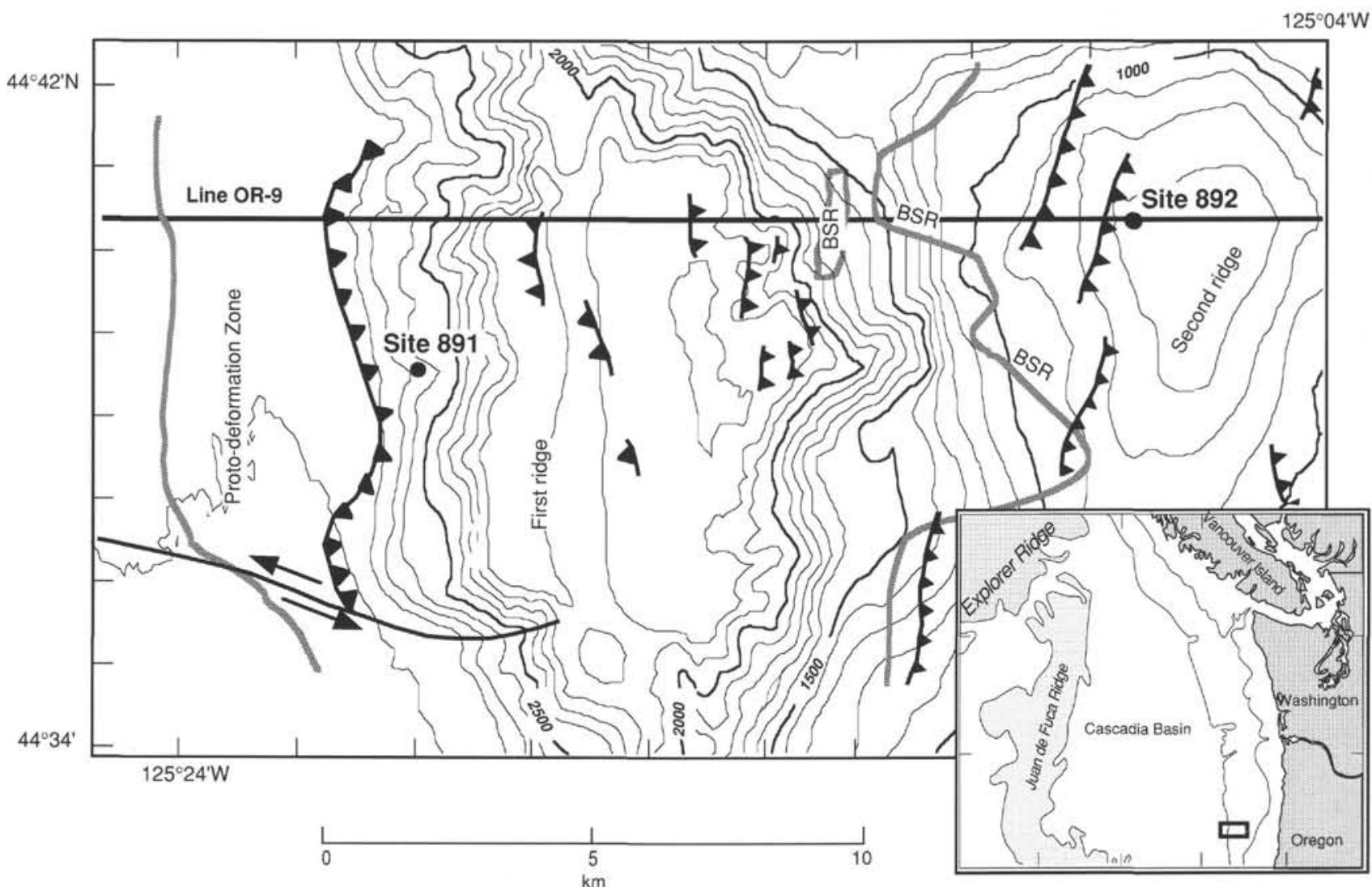

Figure 7. Position of Sites 891 and 892 and seismic line OR-9 off Oregon. The positions of thrust fault traces are indicated by heavy toothed lines. The seaward limits of the proto-deformation zone and of the BSR are shown by heavy gray lines. After MacKay et al. (1992).

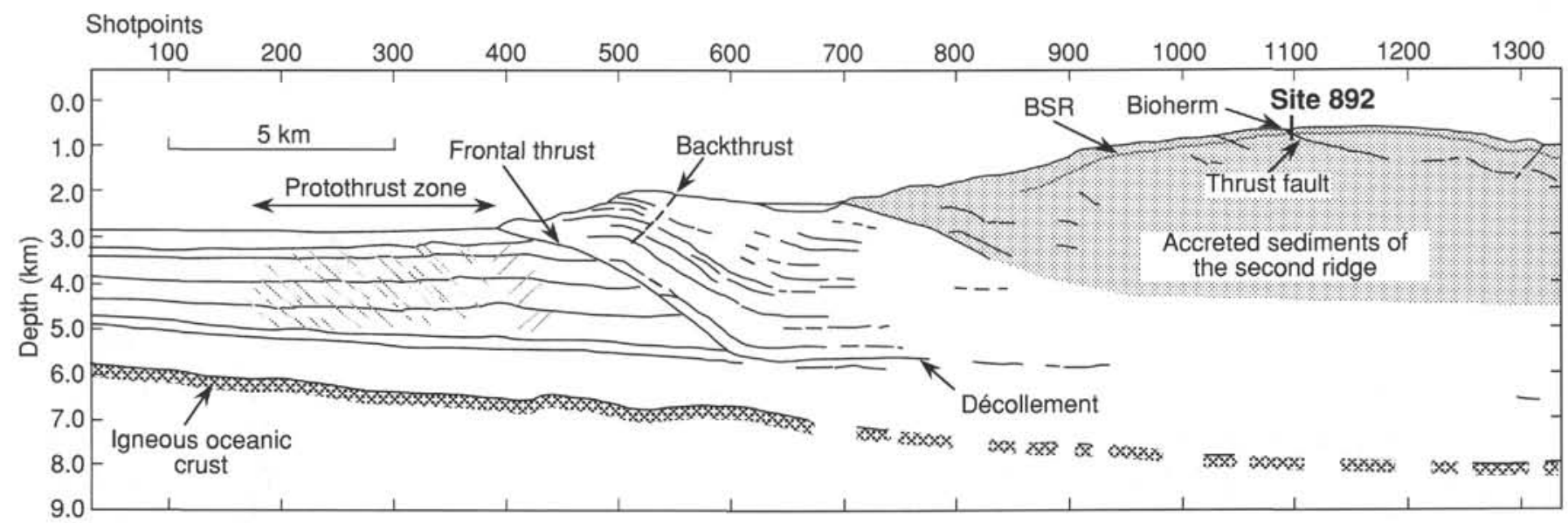

Figure 8. Depth-converted migrated seismic-reflection section OR-9, showing flat-lying Cascadia Basin deposits (Shotpoints 43-150), the proto-deformation zone characterized by blind thrusts (Shotpoints 150-400), the first ridge of the lower slope underlain by a seaward-verging thrust fault (Shotpoints $400-600$ ), and the second ridge (Shotpoints 725-1355). The position of Site 892 is indicated. The structural position of Site 891 was projected from the actual drilling location, $3 \mathrm{~km}$ south. 


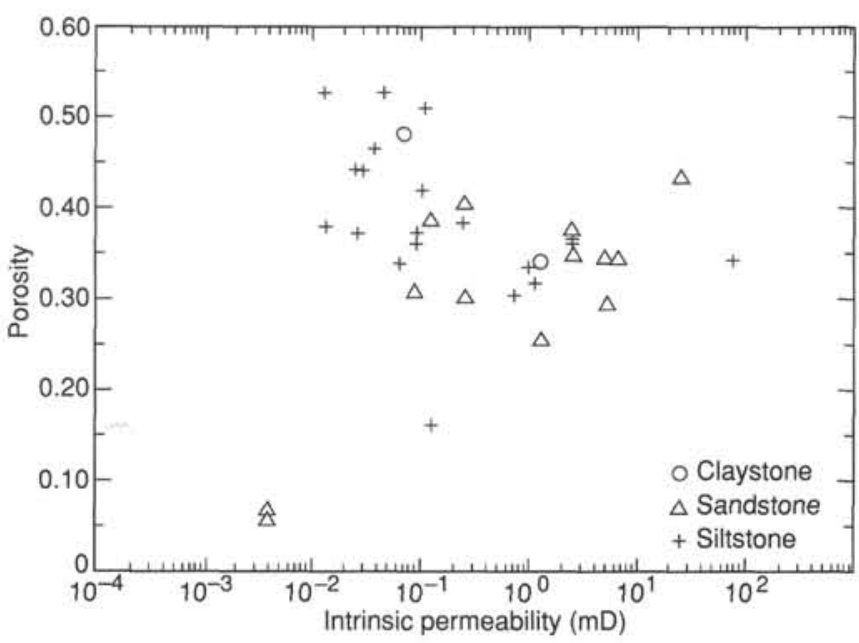

Figure 9. Porosity and permeability of 35 surface samples collected from the seaward side of the marginal ridge of the accretionary wedge off Oregon, depicted in Figure 7. J.C. Moore, by permission.

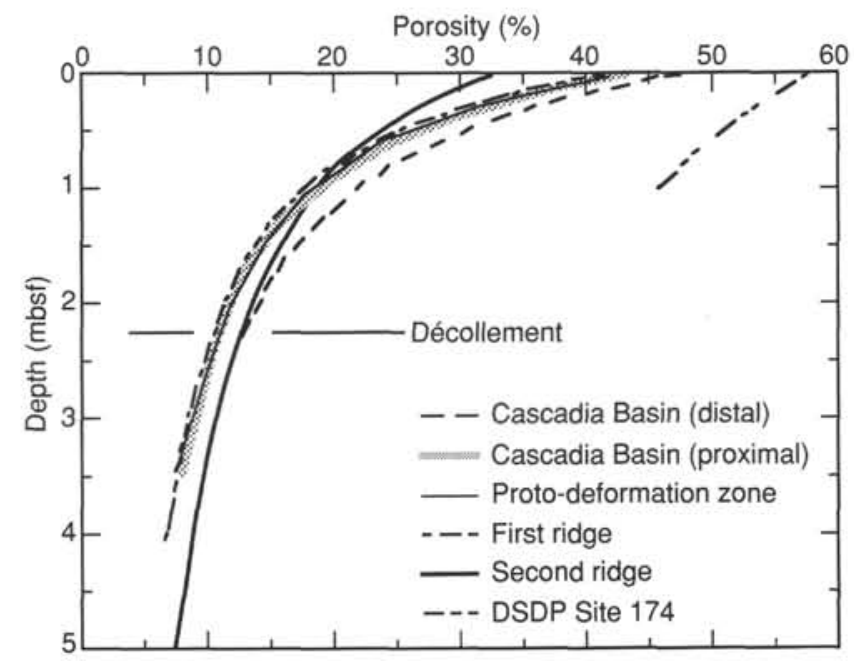

Figure 10. Porosity-depth profiles for Cascadia Basin and the lower continental slope off Oregon, based on seismic refraction, interval migration velocities, and laboratory and downhole velocity-porosity determinations for the Cascadia Margin (after Carson et al., 1991). 